\title{
MENGEMBANGKAN KEMAMPUAN PEMECAHAN MASALAH \\ DAN BELIEF CALON GURU MATEMATIKA MELALUI STRATEGI PERKULIAHAN KOLABORATIF
}

\author{
Djamilah Bondan Widjajanti dan Wahyudin \\ FMIPA Universitas Negeri Yogyakarta dan Sekolah Pascasarjana Universitas \\ Pendidikan Indonesia (e-mail: dj_bondan@yahoo.com; PH: 08179424205)
}

\begin{abstract}
Developing Mathematics Student-Teachers' Problem Solving Competence and Belief Through a Collaborative Learning Strategy. This study aimed to analyze the implementation of a collaborative problem-based learning strategy in developing mathematics student-teachers' problem solving competence and belief in mathematics learning. It was a quasi-experimental study employing a $2 \times 2$ factorial design with two dependent variables. The subjects were 83 students of Mathematics Education Study Program, Faculty of Mathematics and Natural Sciences, Yogyakarta State University, who took the Discrete Mathematics course in the semester of September - December 2009. The instruments were a test on problem-solving competence, a psychological scale to measure the students' belief, observation sheets, and interview guides. The data were analyzed using two-way MANOVA at a significance level of $\alpha=0.05$. The results show that the collaborative problem-based learning strategy is superior to the conventional learning strategy to develop students' problem solving competence and belief in mathematics learning.
\end{abstract}

Keywords: problem-solving, belief, collaborative

\section{PENDAHULUAN}

Banyak faktor yang diduga sebagai penyebab hasil belajar matematika siswa belum memuaskan. Salah satu di antara faktor tersebut adalah masih banyak siswa yang menganggap matematika sebagai pelajaran yang sangat sulit dan kurang kegunaannya, kecuali untuk berhitung. Akibatnya, sebagian siswa tidak cukup antusias dan percaya diri dalam belajar matematika.

Bagaimanapun, para guru matematika memegang peranan penting dalam memberikan gambaran yang wajar tetang pelajaran matematika kepada sis- wa. Pengalaman belajar matematika yang didapatkan para siswa dalam kelas tentu berpengaruh terhadap gambaran mereka terhadap pelajaran matematika. Gambaran bahwa matematika kurang tampak kegunaannya, boleh jadi sebagai akibat kurangnya siswa mendapat pengalaman untuk belajar memecahkan masalah, khususnya masalah-masalah matematika yang berkaitan dengan dunia nyata. Oleh karena itu, pendekatan kontekstual akhir-akhir ini direkomendasikan para ahli pendidikan untuk diimplementasikan para guru di sekolah. 
Pendekatan kontekstual didasarkan pada filsafat konstruktivisme. Menurut paham konstruktivisme, pengetahuan tidak dapat ditransfer dari seorang guru kepada siswa begitu saja, tetapi harus diinterpretasikan sendiri oleh masingmasing siswa (Suparno, 1996:68). Pendekatan kontekstual merupakan konsep belajar yang membantu guru mengaitkan materi yang diajarkan dengan situasi dunia nyata siswa dan mendorong siswa membuat hubungan antara pengetahuan yang dimilikinya dengan penerapannya dalam kehidupan mereka sebagai anggota keluarga dan masyarakat (Departemen Pendidikan Nasional, 2002:1).

Oleh karena itu, seorang guru matematika dituntut untuk kreatif mencari atau membuat masalah matematis yang kontekstual dan menguasai berbagai strategi untuk menyelesaikannya. Dengan demikian, mempunyai kemampuan pemecahan masalah matematis sangatlah penting bagi seorang guru matematika.

Langkah yang terkenal dalam pemecahan masalah matematis dikemukakan oleh G. Polya, dalam buku "How to Solve It". Empat langkah pemecahan masalah matematika menurut G. Polya tersebut adalah: "(1) understanding the problem; (2) devising a plan; (3) carrying out the plan; (4) looking back" (alfeld, 1996).

Menurut standar National Council of Teacher of Mathematics (2003), indikator yang dapat menunjukkan apakah seorang calon guru matematika telah mempunyai kemampuan pemecahan masalah matematis adalah dapat: (1) Menerapkan dan mengadaptasi ber- bagai pendekatan dan strategi untuk menyelesaikan masalah; (2) menyelesaikan masalah yang muncul di dalam matematika atau di dalam konteks lain yang melibatkan matematika; (3) membangun pengetahuan matematis yang baru lewat pemecahan masalah; dan (4) memonitor dan merefleksi pada proses pemecahan masalah matematis.

Selain memiliki kemampuan pemecahan masalah matematis, seorang guru matematika haruslah mempunyai keyakinan (belief) yang positif terhadap matematika dan proses pembelajarannya. Tanpa memiliki keyakinan yang demikian, besar kemungkinan para guru matematika justru akan semakin menguatkan gambaran tentang matematika sebagai pelajaran yang sangat sulit bagi sebagian siswa. Bagaimanapun, keyakinan seseorang guru matematika terhadap matematika dan proses belajar mengajarnya akan berpengaruh terhadap apa yang akan dilakukannya dalam mengajar, sebagaimana Beswick (2006) menyatakan: “...that what teachers believe influences their teaching". Juga Ernest (1989) menyatakan, "...the practice of teaching mathematics depends on a number of key elements, most notably the teacher's mental contents or schemas, particularly the system of beliefs concerning mathematics and its teaching and learning".

Shaw dan Wright menyebutkan belief sebagai konstruk psikologis yang menekankan taraf penerimaan proposisi tentang karakteristik suatu objek atau karakteristik suatu peristiwa (Suryanto, 2001:5). Beswick (2006) menyatakan bahwa belief adalah "anything that an individual regards as true", sedangkan 
Chapman (2008) menyatakan bahwa belief merujuk pada sesuatu yang oleh seseorang dianggap benar, dan itu dapatberasal dari pengalaman, nyata maupun hanya dibayangkan.

Terkait belief terhadap matematika, Schoenfeld (1992:68) mendefinisikan sebagai "An individual's understanding and feelings that shape the ways that the individual conceptualizes and engages in mathematical behavior". Belief yang positif terhadap matematika merupakan hal penting yang harus ditanamkan pada anak sejak dini mengingat belief dapat menjadi dasar untuk disposisi, dasar untuk bertindak, dasar untuk berubah, dan dasar untuk belajar (Chapman, 2008). Pehkonen, et.al., (2003) bahkan menyatakan bahwa antara belief terhadap matematika dan belajar matematika saling berkaitan membentuk suatu proses yang melingkar. Bagaimana matematika diajarkan di kelas, sedikit demi sedikit, mempengaruhi belief siswa terhadap matematika. Juga sebaliknya, belief mempengaruhi bagaimana cara siswa "menyambut" pelajaran matematikanya.

Karena para guru matematikalah yang berperan dalam membangun gambaran siswa tentang pelajaran matematika, maka program pendidikan untuk calon guru matematika haruslah menaruh perhatian yang sangat serius terhadap pembekalan ketrampilan memecahkan masalah matematis dan pembentukan sikap positif terhadap matematika dan pembelajarannya, bagi para mahasiswanya.

Namun, berdasarkan studi pendahuluan yang telah dilakukan oleh peneliti di Program Studi Pendidikan Ma- tematika FMIPA UNY pada tahun 2008, dapat diketahui bahwa para mahasiswa calon guru matematika, baik mahasiswa program reguler maupun mahasiswa program nonreguler, kebanyakan lemah dalam hal pemecahan masalah matematis. Nampaknya, pendekatan perkuliahan secara konvensional yang pada umumnya dilaksanakan oleh para dosen, diduga kurang memberi peluang kepada para mahasiswa untuk meningkatkan kemampuan pemecahan masalah matematis. Dengan demikian, diperlukan pendekatan perkuliahan yang lain, yang menghadapkan para mahasiswa pada beragam masalah nyata yang harus dicari strategi penyelesaiannya.

Pendekatan pembelajaran berbasis masalah (Problem-based Learning, disingkat PBL), secara teori diduga kuat cukup menjanjikan kemungkinan untuk dapat meningkatkan kemampuan pemecahan masalah matematis para mahasiswa calon guru matematika karena mempunyai karakteristik: (1) pembelajaran dipandu oleh masalah yang menantang; (2) para mahasiswa bekerja dalam kelompok kecil; dan (3) dosen mengambil peran sebagai "fasilitator" dalam perkuliahan. PBL menampilkan perkuliahan sebagai kegiatan pemecahan masalah bagi mahasiswa. Dalam rangka menyelesaikan masalah tersebut para mahasiswa akan belajar dalam kelompok kecil, saling mengajukan ide kreatif mereka, berdiskusi, dan berfikir secara kritis (Roh, 2003). Juga, mahasiswa-mahasiswa yang mengikuti perkuliahan dengan pendekatan PBL mempunyai kesempatan yang lebih besar untuk belajar proses matematika yang 
berkaitan dengan komunikasi, representasi, pemodelan, dan penalaran. Dibandingkan pendekatan pembelajaran tradisional, PBL membantu para mahasiswa dalam mengonstruksi pengetahuan dan ketrampilan penalaran (Tan, 2004: 7).

Kerka (Weissinger, 2004:49) menyatakan bahwa dengan bertanya-jawab, mendapat dorongan, latihan, dan peragaan dari tutor, maka kesempatan belajar suatu keahlian tertentu atau strategi lain yang juga berdasar teori konstruktivisme, telah dikembangkan dalam konteks PBL. Dalam Wikipedia juga disebutkan bahwa para pendukung atau penganjur PBL menyatakan PBL dapat digunakan untuk meningkatkan pengetahuan siswa atau mahasiswa dan membantu mereka mengembangkan komunikasi, pemecahan masalah, serta ketrampilan belajar mandiri. Duch, et.al. (2000) juga menyebutkan bahwa PBL memberikan lingkungan yang diperlukan oleh mahasiswa untuk mengembangkan kompetensi-kompetensi yang diperlukan untuk menjadi sukses.

Meskipun PBL diyakini mempunyai sejumlah keunggulan jika dibandingkan dengan pembelajaran konvensional, namun dijumpai juga beberapa kendala dalam pelaksanaan PBL. Salah satu kendala tersebut adalah keheterogenan mahasiswa, baik pada aspek kemampuan awal, tingkat dan kecepatan berpikir, maupun motivasi belajar. Bagaimanapun, para dosen tidak dapat mengabaikan keheterogenan mahasiswa ini jika berharap dapat menjamin hak setiap mahasiswa untuk memperoleh pembelajaran yang bermakna.
Untuk mengatasi dampak dari keheterogenan mahasiswa, diperlukan model pembelajaran yang memberi lebih banyak peluang kepada mahasiswa untuk dapat saling belajar dari mahasiswa lain. Model pembelajaran kolaboratif dapat menjadi pilihan untuk memberi peluang tersebut. Menurut Sato (2007:3) pembelajaran kolaboratif adalah pembelajaran yang dilaksanakan dalam kelompok, namun tujuannya bukan untuk mencapai kesatuan yang didapat melalui kegiatan kelompok, namun, para siswa dalam kelompok didorong untuk menemukan beragam pendapat atau pemikiran yang dikeluarkan oleh tiap individu dalam kelompok. Pembelajaran tidak terjadi dalam kesatuan, namun pembelajaran merupakan hasil dari keragaman atau perbedaan.

Pada dasarnya pembelajaran kolaboratif merujuk pada suatu metode pembelajaran dengan mahasiswa dari tingkat performa yang berbeda (heterogen) bekerja bersama dalam suatu kelompok kecil. Setiap mahasiswa ikut bertanggung jawab terhadap pembelajaran mahasiswa yang lain, sehingga kesuksesan seorang mahasiswa diharapkan dapat membantu siswa atau mahasiswa lain untuk menjadi sukses (Gokhale, 1995). Selain menjembatani keheterogenan, model perkuliahan kolaboratif juga memungkinkan mahasiswa untuk lebih serius saling belajar "sesuatu" dari kelompoknya, termasuk bagaimana menyelesaikan masalah yang diberikan oleh dosen. Gabungan antara pendekatan perkuliahan berbasis masalah dan model perkuliahan kolaboratif inilah yang selanjutnya disebut dengan stra- 
tegi perkuliahan kolaboratif berbasis masalah.

\section{METODE}

Jenis penelitian ini adalah quasi eksperimen, dengan 1 faktor perlakuan yang dikenakan pada subjek penelitian, yaitu pemberian perkuliahan dengan strategi tertentu (konvensional, atau kolaboratif berbasis masalah) dan 1 faktor lingkungan, yaitu jenis program yang ditempuh mahasiswa (reguler atau nonreguler). Ada dua variabel terikat atau respon yang diamati pada subjek penelitian, yaitu: (1) kemampuan pemecahan masalah matematis; dan (2) keyakinan terhadap pembelajaran matematika. Rancangan penelitiannya adalah faktorial $2 \times 2$ dengan 2 varibel terikat, dengan kategori Multivariate Two-Way Fixed Model with interaction (Johnson, R.A, and Wichern, D.W., 1998:309).

Subjek penelitian ini 83 mahasiswa Prodi Pendidikan Matematika, FMIPA Universitas Negeri Yogyakarta yang menempuh perkuliahan Matematika Diskret pada semester September - Desember 2009. Kelas kontrol yang terdiri dari 23 mahasiswa program reguler dan 21 mahasiswa program nonreguler mendapat perkuliahan menggunakan strategi konvensional, sedangkan kelas eksperimen yang terdiri dari 17 mahasiswa program reguler dan 22 mahasiswa program nonreguler mendapatkan perkuliahan menggunakan strategi kolaboratif berbasis masalah.
Instrumen yang digunakan adalah soal tes kemampuan pemecahan masalah, skala psikologi untuk mengukur peningkatan keyakinan mahasiswa, lembar observasi, dan pedoman wawancara. Semua instrumen ini dibuat sendiri oleh peneliti, dengan memperhatikan ketentuan pembuatan instrumen yang baik, serta melalui pertimbangan validator dan diujicobakan.

Untuk menguji hipotesis digunakan program SPSS versi 17, khususnya untuk General Linear Model, pada bagian Multivariate. Ada tiga macam pengujian hipotesis yang dilakukan secara serentak menggunakan MANOVA 2 jalur, yaitu yang menyangkut pengaruh faktor pertama (strategi perkuliahan), faktor kedua (jenis program), dan interaksi kedua faktor tersebut, terhadap kedua respon yang diamati. Pengujian dilakukan pada taraf signifikansi 5\%. Profile Plots untuk skor kedua variabel terikat ditampilkan untuk melihat secara visual pola interaksi antar faktor yang terlibat dalam penelitian ini.

\section{HASIL}

Untuk mendapatkan gambaran perolehan skor kemampuan pemecahan masalah matematis (KPM) dan peningkatan skor keyakinan terhadap pembelajaran matematika (PKY) dari mahasiswa yang menjadi subyek penelitian ini, berikut ini disajikan beberapa statistik dari data keduanya yang dihitung dari data penelitian ini. 


\section{Tabel 1. Statistik Data Kemampuan Pemecahan Masalah Matematis dan Peningkatan Keyakinan terhadap Pembelajaran Matematika}

\begin{tabular}{|c|c|c|c|c|c|c|c|}
\hline \multirow{2}{*}{ Program } & \multirow{2}{*}{ Statistik } & \multicolumn{2}{|c|}{ Kelas Kontrol (K) } & \multicolumn{2}{|c|}{ Kelas Eksperimen (E) } & \multicolumn{2}{|c|}{ Kelas K + E } \\
\hline & & KPM & PKY & KPM & PKY & KPM & PKY \\
\hline \multirow{5}{*}{$\begin{array}{l}\text { Reguler } \\
\text { (R) }\end{array}$} & Ukuran & \multicolumn{2}{|c|}{23} & \multicolumn{2}{|c|}{17} & \multicolumn{2}{|c|}{40} \\
\hline & Skor terkecil & 6 & $-7,38$ & 8 & 1,76 & 6 & $-7,38$ \\
\hline & Rata-rata skor & 14,39 & 1,98 & 16,76 & 8,19 & 15,40 & 4,62 \\
\hline & Simp. Baku & 4,92 & 5,92 & 5,04 & 4,09 & 5,05 & 6,02 \\
\hline & Skor terbesar & 24 & 12,81 & 26 & 16,71 & 26 & 16,71 \\
\hline \multirow{5}{*}{$\begin{array}{c}\text { Non } \\
\text { Reguler } \\
\text { (NR) }\end{array}$} & Ukuran & \multicolumn{2}{|c|}{21} & \multicolumn{2}{|c|}{22} & \multicolumn{2}{|c|}{43} \\
\hline & Skor terkecil & 3 & $-5,82$ & 5 & $-7,04$ & 3 & $-7,04$ \\
\hline & Rata-rata skor & 8,62 & 2,24 & 13,00 & 7,94 & 10,86 & 5,16 \\
\hline & Simp. Baku & 4,24 & 4,25 & 4,11 & 4,97 & 4,68 & 5,41 \\
\hline & Skor terbesar & 18 & 8,75 & 21 & 15,74 & 21 & 15,74 \\
\hline \multirow{5}{*}{$\mathrm{R}+\mathrm{NR}$} & Ukuran & \multicolumn{2}{|c|}{44} & \multicolumn{2}{|c|}{39} & \multicolumn{2}{|c|}{83} \\
\hline & Skor terkecil & 3 & $-7,38$ & \multicolumn{2}{|r|}{$-7,04$} & \multicolumn{2}{|c|}{738} \\
\hline & Rata-rata skor & 11,64 & 2,11 & 14,64 & 8,05 & 13,05 & 4,90 \\
\hline & Simp. Baku & 5,41 & 5,13 & 4,86 & 4,55 & 5,34 & 5,68 \\
\hline & Skor terbesar & 24 & 12,81 & 26 & 16,71 & 26 & 16,71 \\
\hline
\end{tabular}

Sumber: Data Penelitian

Tampak pada Tabel 1 bahwa ratarata skor kelas eksperimen lebih besar dari rata-rata skor kelas kontrol, baik untuk KPM maupun PKY. Jika kita hanya membandingkan statistik kelompok mahasiswa program reguler dan non reguler, tampak bahwa hanya ratarata skor KPM dari mahasiswa program reguler yang lebih besar dari rata-rata skor mahasiswa program non reguler. Untuk PKY, rata-rata skor mahasiswa non reguler justru lebih besar dari ratarata skor mahasiswa reguler. Namun, untuk menyimpulkan apakah statistik ini cukup dapat mendukung diterimanya hipotesis pertama dalam penelitian ini, masih diperlukan suatu pengujian secara statistik.

Hipotesis utama yaitu "Terdapat pengaruh strategi perkuliahan, jenis program, dan gabungan strategi perkuliahan dan jenis program, terhadap kemampuan pemecahan masalah matematis dan peningkatan keyakinan mahasiswa terhadap pembelajaran matematika", diuji menggunakan taraf signifikansi $\alpha=0,05$, dengan hasil pengujian sebagai berikut. 
Tabel 2. Hasil Uji Manova

\begin{tabular}{llrrrrr}
\hline Pengaruh & Statistik & Nilai & F & df hipotesis & df galat & Sig. $\left.{ }^{*}\right)$ \\
\hline Intercept & Pillai's Trace & 0,911 & 400,354 & 2 & 78 & 0,000 \\
& Wilks' Lambda & 0,089 & 400,354 & 2 & 78 & 0,000 \\
& Hotelling's Trace & 10,265 & 400,354 & 2 & 78 & 0,000 \\
& Roy's Largest Root & 10,265 & 400,354 & 2 & 78 & 0,000 \\
Strategi & Pillai's Trace & 0,358 & 21,794 & 2 & 78 & 0,000 \\
& Wilks' Lambda & 0,642 & 21,794 & 2 & 78 & 0,000 \\
& Hotelling's Trace & 0,559 & 21,794 & 2 & 78 & 0,000 \\
& Roy's Largest Root & 0,559 & 21,794 & 2 & 78 & 0,000 \\
Program & Pillai's Trace & 0,221 & 11,043 & 2 & 78 & 0,000 \\
& Wilks' Lambda & 0,779 & 11,043 & 2 & 78 & 0,000 \\
& Hotelling's Trace & 0,283 & 11,043 & 2 & 78 & 0,000 \\
& Roy's Largest Root & 0,283 & 11,043 & 2 & 78 & 0,000 \\
Program & *illai's Trace & 0,013 & 0,498 & 2 & 78 & 0,609 \\
& Wilks' Lambda & 0,987 & 0,498 & 2 & 78 & 0,609 \\
& Hotelling's Trace & 0,013 & 0,498 & 2 & 78 & 0,609 \\
& Roy's Largest Root & 0,013 & 0,498 & 2 & 78 & 0,609 \\
\hline
\end{tabular}

*) Nilai signifikansi dibulatkan dalam 3 angka dibelakang koma menjadi 0,000 berarti bahwa nilai sebelum dibulatkan kurang dari 0,0005

Berdasarkan nilai signifikansi dari masing-masing statistik uji pada kolom terakhir Tabel 2, dapat disimpulkan bahwa di bawah taraf signifikansi $\alpha=$ 0,05 , baik menggunakan statistik uji Pillai's Trace, Wilks' Lambda, Hotelling's Trace, maupun Roy's Largest Root, ternyata: (1) terdapat pengaruh faktor strategi perkuliahan terhadap respon yang diamati; (2) terdapat pengaruh faktor jenis program terhadap respon yang diamati; namun (3) tidak terdapat penga- ruh gabungan (interaksi) kedua faktor terhadap respon yang diamati.

Pada pengujian menggunakan Manova di atas, yang dimaksud dengan respons yang diamati adalah KPM dan PKY dilihat sebagai sebuah kesatuan. Lebih rinci, jika dilihat pengaruh masing-masing faktor dan gabungannya terhadap setiap respons, terpisah dengan respon yang lain, maka hasil perhitungan program SPSS 17 untuk pengujian pengaruh masing-masing faktor dan gabungannya tertera pada Tabel 3 Berikut. 
Tabel 3. Hasil Pengujian Pengaruh Faktor terhadap Masing-Masing Respons

\begin{tabular}{|c|c|c|c|c|c|c|}
\hline \multirow[b]{2}{*}{ Sumber } & \multirow{2}{*}{$\begin{array}{c}\text { Variabel } \\
\text { Terikat }\end{array}$} & \multirow{2}{*}{$\begin{array}{l}\text { Jumlah } \\
\text { Kuadrat }\end{array}$} & \multicolumn{3}{|c|}{ Rata-rata Jumlah } & \multirow[b]{2}{*}{ Sig.*) } \\
\hline & & & $\mathrm{df}$ & Kuadrat & $\mathrm{F}$ & \\
\hline \multirow{2}{*}{$\begin{array}{l}\text { Corrected } \\
\text { Model }\end{array}$} & KPM & 688,318 & 3 & 229,439 & 10,962 & 0,000 \\
\hline & PKY & 731,741 & 3 & 243,914 & 10,053 & 0,000 \\
\hline \multirow[t]{2}{*}{ Intercept } & KPM & 14255,669 & 1 & 14255,669 & 681,104 & 0,000 \\
\hline & PKY & 2120,927 & 1 & 2120,927 & 87,419 & 0,000 \\
\hline \multirow[t]{2}{*}{ Strategi } & KPM & 233,506 & 1 & 233,506 & 11,156 & 0,001 \\
\hline & PKY & 725,690 & 1 & 725,690 & 29,911 & 0,000 \\
\hline \multirow[t]{2}{*}{ Program } & KPM & 465,533 & 1 & 465,533 & 22,242 & 0,000 \\
\hline & PKY & 0,001 & 1 & 0,001 & 0,000 & 0,994 \\
\hline \multirow{2}{*}{$\begin{array}{l}\text { Strategi * } \\
\text { Program }\end{array}$} & KPM & 20,628 & 1 & 20,628 & 0,986 & 0,324 \\
\hline & PKY & 1,294 & 1 & 1,294 & 0,053 & 0,818 \\
\hline \multirow[t]{2}{*}{ Error } & KPM & 1653,489 & 79 & 20,930 & & \\
\hline & PKY & 1916,666 & 79 & 24,262 & & \\
\hline \multirow[t]{2}{*}{ Total } & KPM & 16473,000 & 83 & & & \\
\hline & PKY & 4640,649 & 83 & & & \\
\hline \multirow{2}{*}{$\begin{array}{l}\text { Corrected } \\
\text { Total }\end{array}$} & KPM & 2341,807 & 82 & & & \\
\hline & PKY & 2648.407 & 82 & & & \\
\hline
\end{tabular}

*) Nilai signifikansi dibulatkan dalam 3 angka dibelakang koma menjadi 0,000 berarti bahwa nilai sebelum dibulatkan kurang dari 0,0005

Memperhatikan bahwa setiap faktor hanya terdiri 2 taraf, perolehan rata-rata KPM dan PKY pada Tabel 1, dan nilai signifikansi pada kolom terakhir Tabel 3 di atas, maka di bawah taraf signifikansi $\alpha=0,05$, dapat disimpulkan: : (1) KPM mahasiswa yang mendapatkan perkuliahan dengan strategi kolaboratif berbasis masalah dapat dianggap lebih tinggi dibandingkan KPM mereka yang mendapatkan perkuliahan secara konvensional; (2) KPM mahasiswa program reguler dapat dianggap lebih tinggi dibandingkan KPM mahasiswa program nonreguler; (3) PKY dari mahasiswa yang mendapatkan perkuliahan dengan strategi perkuliahan kolaboratif berba- sis masalah dapat dianggap lebih tinggi dari PKY mereka yang mendapatkan perkuliahan secara konvensional; (4) PKY mahasiswa program reguler tidak dapat dianggap lebih tinggi dibandingkan PKY mahasiswa program nonreguler; (5) Tidak terdapat pengaruh gabungan (interaksi) antara strategi perkuliahan dan jenis program terhadap KPM mahasiswa; dan (6) tidak terdapat pengaruh gabungan (interaksi) antara strategi perkuliahan dan jenis program terhadap PKY mahasiswa.

Tidak adanya interaksi kedua faktor terhadap masing-masing respon yang diamati tergambarkan pada Gambar 1 dan Gambar 2 berikut ini. 


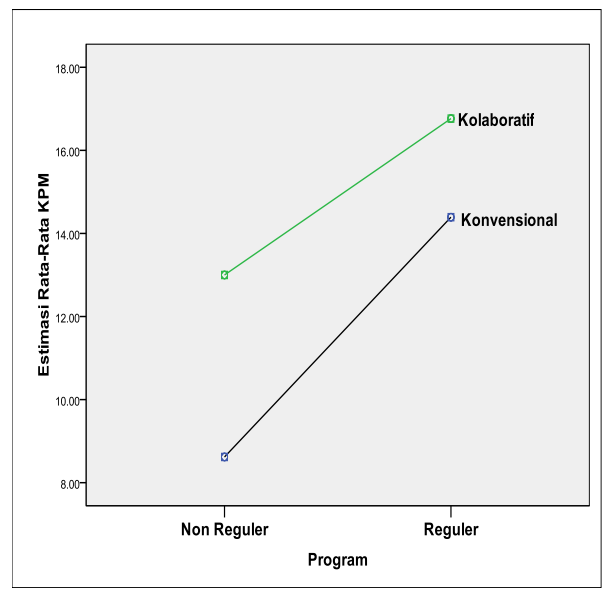

Gambar 1. Grafik Interaksi Kedua Faktor terhadap KPM

Tampak pada Gambar 1 dan Gambar 2 di atas bahwa rata-rata KPM dan PKY mahasiswa kelas kolaboratif lebih besar dari rata-rata KPM dan PKY mahasiswa kelas konvensional, baik untuk mahasiswa program reguler maupun nonreguler. Tampak juga bahwa besar pengaruh faktor strategi perkuliahan tersebut terhadap KPM dan PKY relatif sama besarnya untuk mahasiwa program reguler dan nonreguler.

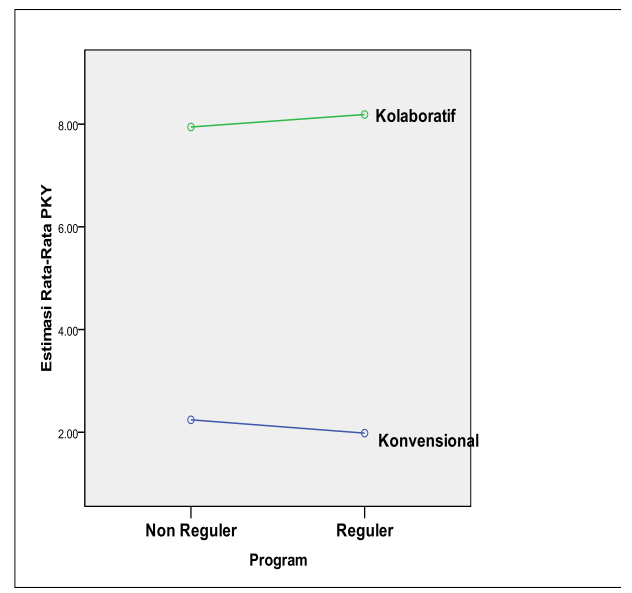

Gambar 1. Grafik Interaksi Kedua Faktor terhadap PKY

Meskipun secara rata-rata skor KPM dari kelas kolaboratif (kelas eksperimen) lebih besar dari rata-rata skor KPM kelas konvensional (kelas kontrol), dan rata-rata skor KPM dari mahasiswa program reguler yang lebih besar dari rata-rata skor KPM mahasiswa program non reguler namun perolehan rata-rata tersebut, untuk setiap nomor soal, keduanya hanya 31\% s.d.55\% dari skor maksimal yang mungkin sebagaimana tampak pada Tabel 4 berikut.

Tabel 4. Rata-rata Skor Kemampuan Pemecahan Masalah Matematis Per Nomor Soal

\begin{tabular}{|c|c|c|c|c|c|}
\hline \multirow{2}{*}{ Soal Nomor } & \multirow{2}{*}{$\begin{array}{l}\text { Skor Maksimal } \\
\text { yang mungkin }\end{array}$} & \multicolumn{4}{|c|}{ Rata-rata Skor } \\
\hline & & $\mathrm{K}$ & $\mathrm{E}$ & $\mathrm{R}$ & NR \\
\hline 1 & 9 & 2,98 & 4,85 & 4,60 & 3,21 \\
\hline 2 & 9 & 3,28 & 3,69 & 4,22 & 2,79 \\
\hline 3 & 12 & 5,28 & 6,10 & 6,58 & 4,86 \\
\hline
\end{tabular}

Sumber: Data Penelitian

Perolehan skor awal, skor akhir, dan peningkatannya, untuk keyakinan terhadap pembelajaran matematika dari kelas kontrol dan kelas eksperimen ter-

saji pada Tabel 5 berikut. Tampak bahwa rata-rata skor awal kedua kelas relatif hampir sama besarnya. 
Tabel 5. Statistik Peningkatan Keyakinan terhadap Pembelajaran Matematika untuk Mahasiswa Kelas Kontrol (K) dan Kelas Eksperimen (E)

\begin{tabular}{lcccccc}
\hline \multirow{2}{*}{ Statistik } & \multicolumn{2}{c}{ Skor Awal } & \multicolumn{2}{c}{ Skor Akhir } & \multicolumn{2}{c}{ Peningkatan } \\
\cline { 2 - 7 } & $\mathrm{K}$ & $\mathrm{E}$ & $\mathrm{K}$ & $\mathrm{E}$ & $\mathrm{K}$ & $\mathrm{E}$ \\
\hline Skor terkecil & 65,77 & 68,73 & 68,08 & 74,31 & $-7,38$ & $-7,04$ \\
Rata-rata skor & $\mathbf{8 4 , 8 8}$ & $\mathbf{8 5 , 7 1}$ & $\mathbf{8 6 , 9 9}$ & $\mathbf{9 3 , 7 6}$ & $\mathbf{2 , 1 1}$ & $\mathbf{8 , 0 5}$ \\
Simpangan baku & 9,50 & 8,54 & 8,65 & 9,39 & 5,13 & 4,55 \\
Skor terbesar & 109,64 & 108,41 & 106,5 & 117,76 & 12,81 & 16,71 \\
\hline
\end{tabular}

Sumber: Data Penelitian

Terkait dengan PKY, beberapa temuan tentang perubahan persentase pilihan jawaban untuk beberapa butir pernyataan berikut ini cukup menarik untuk dikaji lebih jauh. Butir pernyataan "Mengetahui asal usul diperolehnya rumus matematika sangat penting bagi siswa" semula responden yang sangat setuju, baik di kelas kontrol maupun kelas eksperimen, sama-sama sebesar 36\%, namun di akhir perkuliahan persentase tersebut untuk kelas kontrol dan kelas eksperimen berturut-turut berubah menjadi $43 \%$ dan $51 \%$. Untuk butir pernyataan "Belajar matematika dapat menjadi kegiatan yang menyenangkan" persentase tersebut berturut-turut untuk kelas kontrol dan kelas ekperimen semula $27 \%$ dan $23 \%$, berubah menjadi $36 \%$ dan $51 \%$.

Demikian juga untuk butir pernyataan negatif berikut ini. Persentase jawaban setuju untuk pernyataan "Metode ceramah dengan pemberian contoh-contoh dan latihan soal-soal, paling tepat untuk mengajarkan matematika" di kelas kontrol dan kelas eksperimen pada awalnya sama sebesar 36\%, namun di akhir perkuliahan persentase tersebut berubah menjadi 50\% di kelas kontrol dan 5\% di kelas eksperimen.
Pernyataan "Metode diskusi tidak cocok untuk mengajarkan matematika" semula dijawab sangat setuju oleh $14 \%$ responden di kelas kontrol dan 10\% responden di kelas eksperimen, namun pada akhir perkuliahan persentase tersebut berubah menjadi $18 \%$ di kelas kontrol dan 33\% di kelas eksperimen.

Dari pengamatan observer dan dari rekaman pelaksanaan perkuliahan baik di kelas kontrol maupun di kelas eksperimen, dapat diketahui bahwa kesiapan, keterlibatan, dan antusiasme mahasiswa di kelas eksperimen lebih tinggi dibandingkan kesiapan, keterlibatan, dan antusiasme mahasiswa di kelas kontrol.

\section{PEMBAHASAN}

Hasil penelitian ini yang menyatakan keunggulan strategi perkuliahan kolaboratif berbasis masalah dibandingkan strategi perkuliahan konvensional, khususnya dalam mengembangkan KPM dan PKY mahasiswa, telah sesuai hipotesis peneliti. Hasil yang demikian ini sungguh wajar, sebab strategi perkuliahan kolaboratif berbasis masalah memang sengaja dirancang untuk memberi peluang mahasiswa mengembangkan kemampuan mereka dalam peme- 
cahan masalah matematis sekaligus memperoleh pengalaman belajar yang konstruktivis.

Dasar dari perkuliahan yang menggunakan strategi kolaboratif berbasis masalah adalah penggunaan masalah untuk memandu, mengemudikan, menggerakkan, atau mengarahkan pembelajaran, dan pemanfaataan diskusi untuk menumbuhkan kolaborasi. Dengan dasar yang demikian, sudah sewajarnya jika hasil penelitian ini menunjukkan bahwa perkuliahan yang menggunakan strategi kolaboratif berbasis masalah mampu memberikan hasil yang lebih baik, minimal pada 2 respon yang diamati dalam penelitian ini, dibandingkan perkuliahan yang menggunakan strategi konvensional. Hasil yang demikian ini juga sesuai dengan pendapat Roh (2003) dan Tan (2004) yang menyebutkan sejumlah keunggulan pendekatan pembelajaran berbasis masalah dibandingkan pendekatan konvensional, khususnya dalam meningkatkan kemampuan penalaran, pemecahan masalah, representasi, pemodelan, dan komunikasi.

Besar kemungkinan keunggulan dari strategi perkuliahan kolaboratif berbasis masalah dibandingkan strategi konvensional tersebut disebabkan pemberian scaffolding yang tepat untuk meningkatkan kemampuan mahasiswa dalam pemecahan masalah matematis dan keyakinan terhadap pembelajaran matematika. Dimulai dengan penyiapan bahan ajar (handout) berbasis masalah sebagai bentuk scaffolding yang pertama dari dosen kepada seluruh mahasiswa. Dengan petunjuk yang jelas agar mahasiswa mencoba terlebih dahulu menye- lesaikan masalah yang diberikan, kemudian baru memberi kesempatan mahasiswa untuk mengklarifikasi pemahaman mereka kepada temannya atau saling belajar dalam kelompok, dan jika diperlukan dosen akan memberi sedikit petunjuk atau arahan, menjadikan mahasiswa mampu bergerak ke ZPD mereka, melampaui kapasitas aktualnya, sesuai dengan konsep ZPD dari teori konstruktivisme sosial Vygotsky (Ibrahim dan Nur, 2000:19; Oakley, 2004:41).

Dari implementasi strategi perkuliahan kolaboratif berbasis masalah pada perkuliahan Matematika Diskret selama 1 semester ini dapat diketahui bahwa keunggulan strategi kolaboratif ini dapat terjadi manakala didukung adanya beberapa hal, antara lain: (1) bahan ajar yang berbasis masalah; (2) munculnya kolaborasi pada saat diskusi; dan (3) intervensi yang tepat dari dosen. Akibatnya, penyusunan bahan ajar menjadi hal pertama yang harus menjadi perhatian dalam implementasi strategi kolaboratif berbasis masalah. Tanpa bahan ajar yang memadai, maka interaksi mahasiswa-dosen, mahasiswa-mahasiswa, dan mahasiswa-materi, tidak akan muncul sesuai yang diharapkan.

Hasil penelitian ini, yang menyatakan KPM mahasiswa program reguler lebih tinggi dari KPM mahasiswa program nonreguler, telah sesuai hipotesis peneliti. Temuan yang demikian ini sangat wajar jika diingat bahwa mahasiswa kedua program mempunyai beberapa perbedaan pada aspek tertentu, khususnya kemampuan akademik. Kelompok mahasiswa program nonreguler, yang sebagian besar di antaranya 
adalah mahasiswa yang tidak lolos seleksi PBU atau SNMPTN, secara ratarata dapat dianggap mempunyai kemampuan akademik yang sedikit lebih rendah dibandingkan kemampuan akademik mahasiswa program reguler sehingga sangat beralasan jika kemampuan pemecahan masalah tidak dapat dianggap sebesar kemampuan mahasiswa program reguler.

Meskipun hasil pengujian hipotesis di atas menunjukkan keunggulan strategi kolaboratif berbasis masalah dalam hal mengembangkanKPM, baik untuk mahasiswa program reguler maupun nonreguler, namun capaian rata-rata skor PKM pada Tabel 4 mengindikasikan adanya "sesuatu" yang masih perlu mendapat perhatian serius. Sesuatu tersebut adalah relatif rendahnya rata-rata skor KPM yang diperoleh subjek penelitian ini, baik dari mahasiswa kelas eksperimen, maupun (apalagi) dari kelas kontrol.

Dari hasil pekerjaan mahasiswa dapatdiketahui rendahnya skor KPM yang diperoleh mahasiswa terutama karena aspek pemahaman masalah yang masih rendah. Mereka lemah dalam memahami informasi yang menunjukkan apa saja yang diketahui. Kalimat “... dan melahirkan 6 pasang kelinci lagi setiap bulannya mulai usia mereka 2 bulan" pada soal nomor 1 ternyata tidak cukup dipahami oleh beberapa mahasiswa, baik di kelas kontrol maupun di kelas eksperimen. Untuk 2 nomor soal yang lain, selain pada pemahaman masalah tampak juga kemampuan memilih strategi yang masih perlu ditingkatkan. Hal yang diduga menjadi penyebab lemahnya mahasiswa dalam aspek memahami masalah dan memilih strategi ini adalah masih kurangnya mereka berlatih mengerjakan soal yang lebih bervariasi. Besar kemungkinan mahasiswa juga hanya mengenal atau memahami beberapa strategi penyelesaian masalah saja. Dengan demikian, untuk dapat mengembangkan KPM mahasiswa, pemberian pengalaman menyelesaikan masalah matematis menggunakan aneka strategi, sebagaimana disebutkan oleh Suherman, dkk. (2003:100) masih sangat diperlukan.

Perubahan persentase jawaban responden terhadap beberapa butir pernyataan yang digunakan untuk mengukur PKY sebagaimana disebut di atas, semakin menunjukkan keunggulan strategi perkuliahan kolaboratif berbasis masalah dibandingkan strategi konvensional. Fakta tersebut telah sesuai dengan harapan peneliti, yaitu bahwa pengalaman belajar yang diperoleh mahasiswa dalam kelas kolaboratif berbasis masalah telah mampu meningkatkan keyakinan mahasiswa, khususnya keyakinan bahwa belajar matematika dapat menjadi kegiatan yang menyenangkan.

Pengalaman belajar memecahkan masalah dengan sedikit petunjuk dosen dan lebih banyak mencoba menyelesaikannya sendiri atau dengan bantuan teman, serta mahasiswa boleh bertanya atau bergabung pada kelompok mana yang ia pandang dapat membantu, ternyata mampu menghadirkan suasana kondusif yang memungkinkan terjadinya interaksi yang kuat antara dosenmahasiswa, mahasiswa-mahasiswa, dan mahasiswa-materi perkuliahan. Di kelas kolaboratif, pilihan jawaban sangat se- 
tuju untuk butir pernyataan "Belajar matematika dapat menjadi kegiatan yang menyenangkan" meningkat dari $23 \%$ menjadi $51 \%$, suatu peningkatan yang meyakinkan, jika dibandingkan peningkatan di kelas kontrol, yaitu dari $27 \%$ menjadi $36 \%$.

Kegiatan perkuliahan pada kelas kontrol didominasi ceramah dosen, dan ini ternyata mengakibatkan mahasiswa di kelas tersebut bertambah yakin bahwa metode ceramah dengan pemberian contoh-contoh dan latihan soal-soal, paling tepat untuk mengajarkan matematika. Sebaliknya, kegiatan perkuliahan di kelas eksperimen didominasi diskusi yang menarik, dan ternyata pengalaman belajar yang demikian ini menurunkan keyakinan mahasiswa terhadap ketepatan penggunaan metode ceramah dalam mengajarkan matematika. Fakta bahwa pengalaman dapat mengubah keyakinan ini sesuai dengan hasil penelitian Hough, et.al.(2006).

\section{PENUTUP}

Berdasarkan hasil pengujian hipotesis dengan menggunakan taraf signifikansi $\alpha=0,05$ dapat disimpulkan bahwa kemampuan pemecahan masalah matematis dan peningkatan keyakinan terhadap pembelajaran matematika, dari mahasiswa calon guru matematika yang mendapatkan perkuliahan menggunakan strategi kolaboratif berbasis masalah dapat dianggap lebih tinggi dibandingkan mereka yang mendapatkan perkuliahan secara konvensional.

Tidak terdapatnya pengaruh gabungan (interaksi) antara strategi perkuliahan dan jenis program terhadap kemampuan pemecahan masalah mate- matis dan keyakinan terhadap pembelajaran matematika berarti bahwa keunggulan strategi kolaboratif berbasis masalah sebagaimana disebut di atas terjadi baik untuk kelompok mahasiswa program reguler maupun non reguler, dengan besar pengaruh yang hampir sama besarnya antara yang diperoleh mahasiswa program reguler dan non reguler.

Dari implementasi strategi perkuliahan kolaboratif berbasis masalah ini dapat diketahui bahwa keyakinan mahasiswa calon guru matematika terhadap pembelajaran matematika dapat dipengaruhi oleh pengalaman belajarnya. Akibatnya, mahasiswa calon guru matematika sangatlah perlu diberi pengalaman belajar yang beragam, konstruktivistik, dan inovatif, agar selama mahasiswa menjalani pendidikannya sebagai calon guru semakin tumbuh keyakinannya yang positif terhadap matematika dan pembelajarannya.

\section{UCAPAN TERIMA KASIH}

Peneliti mengucapkan terima kasih kepada Ketua dan Sekretaris Jurusan Pendidikan Matematika FMIPA UNY atas izin dan fasilitas yang diberikan kepada penulis untuk melakukan penelitian ini. Peneliti juga mengucapkan terima kasih kepada teman-teman dosen Jurdik Matematika FMIPA UNY yang sudah bersedia memberi masukan, baik sebagai validator instrumen maupun observer, dan kepada seluruh mahasiswa Prodi Matematika dan Pendidikan Matematika angkatan 2007, baik sebagai subJek pada uji coba instrumen dan bahan ajar, maupun sebagai subJek penelitian ini. Terakhir, 
penulis juga mengucapkan terima kasih kepada Pengelola dan Dewan Redaksi Jurnal Cakrawala Pendidikan Universitas Negeri Yogyakarta yang telah berkenan mempublikasikan artikel ini.

\section{DAFTAR PUSTAKA}

Alfeld, P. 1996. "Understanding Mathematics" dari http://www.math.utah.edu/ pa/math/polya.html, Diunduh 10 Juli 2007.

Beswick, Kim. 2006. "The Importance of Mathematics Teacher Beliefs" dari http://findarticles.com/p/articles/ mi7030/is462/ diunduh 10 Januari 2009.

Chapman, Olive. 2008. "Self-Study in Mathematics Teacher Education" dari www.unige.ch/math/EndMath/Rome2008/All/Papers/CHA PMAN.pdf, Diunduh 10 Pebruari 2009.

Departemen Pendidikan Nasional. 2002. Pendekatan Kontekstual (Contextual Teaching and Learning). Jakarta: Depdiknas.

Duch, Barbara J., Allen, Deborah E., and White, Harold B. 2000. "Problem-Based Learning: Preparing Students to Succeed in the 21 st Century" dari http://www.hku.hk/caut/homepage/tdg/5/Teachin gMatter/Dec.98.pdf, Diunduh 15 Januari 2008.

Ernest, Paul. 1989. "The Impact of Beliefs on The Teaching of Mathematics" dari http://www.people.exeter.-
ac.uk/PErnest/impact.htm, Diunduh 28 Januari 2009.

Gokhale, A. 1995. "Collaborative Learning Enhances Critical Thinking", Journal of Technology Education, (7) 1, dari http://scolar.lib.vt.edu/ ejournals/ JTE/jte-v7n1/gokhale,jtv7n1.html, diunduh 6 Mei 2008.

Hough, S., Pratt,D.M., Feikes, D. J. 2006. Developing Pre-service Teachers' Beliefs about Mathematics Using a Children's Thinking Approach in Content Area Courses. PME-NA 2006 Proceedings.

Ibrahim, M. \& Nur, M..2000. Pengajaran Berdasarkan Masalah. Surabaya: UNESA-University Press

Johnson, R.A. \& Wichern, D.W. 1998. Applied Multivariate Statistical Analysis. Texas, USA: PrenticeHall International.

National Council of Teachers of Mathematics. 2003. "NCTM Program Standards. Programs for Initial Preparation of Mathematics Teachers. Standards for Secondary Mathematics Teachers" dari: http://www.nctm.org/ uploadedFiles/Math_Standards/, Diunduh 10 Maret 2008.

Oakley, Lisa. 2004. Cognitive Development. London: Routledge-Taylor \& Francis Group.

Pehkonen, E., Nurmi,A.,Hannula, M., \& Maijala, H. 2003. “On Pupils'Self 
Confidence in Mathematics: Gender Comparison" dari http://www.eric.ed.gov/ERICDocs/data,Diunduh 5 Januari 2009

Roh, Kyeong Ha. 2003. "Problem-Based Learning in Mathematics", dalam ERIC Digest. ERIC Identifier: EDO-SE-03-07, dari http://www.ericdigest.org/ , Diunduh 4 Desember 2007.

Sato, Manabu. 2007. Tantangan yang Harus Dihadapi Sekolah, makalah dalam Bacaan Rujukan untuk Lesson Study - Berdasarkan Pengalaman Jepang dan IMSTEP. Jakarta: Sisttems.

Schoenfeld, H. A. 1992. Learning to Think Mathematicaly, in A.D. Grouws (Ed). Handbook of research on $\mathrm{Ma}$ thematics Learning and Teaching.

Suherman, E., Turmudi, Suryadi, D., Herman, T., Suhendra, Prabawanto, S., Nurjanah, Rohayati, H., 2003. Strategi Pembelajaran Matematika Kontemporer. Bandung: UPI dan IMSTEP JICA.
Suryanto. 2001. Aspek Afektif Hasil Pembelajaran Matematika. Laporan Penelitian. Yogyakarta: Jurusan Pendidikan Matematika FMIPA UNY.

Tan, Oon-Seng. 2004. Cognition, Metacognition, and Problem-Based Learning, in Tan, Oon-Seng (Ed) Enhancing Thinking through Problembased Learning Approaches. Singapore: Thomson Learning.

Weissinger, P.A. 2004. Critical Thinking, Metacognition, and Problem-based Learning, in Tan, Oon-Seng (Ed) Enhancing Thinking through Problem-based Learning Approaches. Singapore: Thomson Learning.

Suparno, Paul. 1996. Filsafat Konstruktivisme dalam Pendidikan. Yogyakarta: Penerbit Kanisius. 